\title{
Effect of incubation duration, growth temperature, and abiotic surface type on cell surface properties, adhesion and pathogenicity of biofilm-detached Staphylococcus aureus cells
}

\author{
Simon Oussama khelissa ${ }^{1,2}$, Charafeddine Jama ${ }^{1}$, Marwan Abdallah ${ }^{1}$, Rabah Boukherroub ${ }^{3}$, Christine Faille \\ and Nour-Eddine Chihib ${ }^{2 *}$
}

\begin{abstract}
The goal of this study was to investigate the effect of growth conditions such as the temperature $\left(20,30\right.$ and $\left.37^{\circ} \mathrm{C}\right)$, incubation duration ( 24 and $48 \mathrm{~h}$ ) and surface type (stainless steel and polycarbonate) on the cell surface physicochemical properties and adhesion to abiotic surfaces of biofilm-detached and planktonic Staphylococcus aureus cells. This study tested also the hypothesis that $S$. aureus planktonic cells exhibit distinct pathogenic properties compared with their sessile counterparts. The results showed that the changes of the growth conditions promoted changes in the zeta potential, hydrophobicity, electron donor/acceptor character of the studied cell populations. Biofilmdetached cells showed a greater adhesion to stainless steel and polycarbonate compared with planktonic cells. Compared with planktonic cells, sessile ones showed higher cytotoxic effect against HeLa cells, DNase activity, and siderophore levels. The higher cytotoxic effect and production of DNase and siderophore increased with the increase of temperature and duration of incubations. Based on the obtained data, the S. aureus biofilm-detached cells were found to be distinct in many physiological properties compared with their planktonic counterparts.
\end{abstract}

Keywords: Staphylococcus aureus, Physiology, Planktonic cells, Biofilm-detached cells, Surface properties, Pathogenicity

\begin{abstract}
Introduction
Staphylococcus aureus is an important Gram-positive human pathogen frequently associated with numerous forms of human infections (Harris et al. 2002; Khelissa et al. 2017; Valaperta et al. 2010). S. aureus represents the main cause of hospital acquired infections such as infections associated with indwelling medical devices and surgical wounds (Percival et al. 2015). The pathogenesis of such bacterium correlates with several virulence factors including hemotoxins, pore forming toxins, super antigens (e.g. toxic shock syndrome toxin-1, staphylococcal enterotoxin)
\end{abstract}

\footnotetext{
*Correspondence: nour-eddine.chihib@univ-lille1.fr

${ }^{2}$ CNRS, INRA, UMR 8207-UMET-PIHM, Université de Lille1, 369 rue Jules Guesde, CS 20039, 59651 Villeneuve d'Ascq, France

Full list of author information is available at the end of the article
}

and several secreted enzymes that result in tissue destruction and bacterial dissemination (Normanno et al. 2007). The ability of this bacterium to produce iron acquisition factors (siderophores), such as staphyloferrins A and B, staphylobactin and aureochelin, is also likely important to its pathogenesis (Dale et al. 2004; Oogai et al. 2011). Furthermore, the ability of $S$. aureus to form biofilms and colonize medical devices is regarded as an important virulence determinant in the pathogenesis of this bacterium.

Biofilm is a community of microorganisms attached to abiotic or biotic surfaces and embedded in a protective extracellular polymeric matrix (Donlan 2002). The biofilms are formed on abiotic surfaces through multiple steps, including the adhesion of planktonic cells, maturation, and dispersion of attached cells. Sessile S. aureus cells are particularly problematic and their physiology 
differ distinctly from that of planktonic ones. In fact, sessile cells are much more resistant to the host immune response, antibiotics, biocides and hydrodynamic shear force (Lewis 2001; Garrett et al. 2008). The bacterial adhesion to a surface constitutes the first and the essential step of the biofilm formation (Abdallah et al. 2014a). It has been reported that the physicochemical properties of bacterial and abiotic surfaces, such as the hydrophobicity, the electrostatic charge, and the electron donor/acceptor characters, play a key role in the bacterial attachment to abiotic surfaces (Abdallah et al. 2014a). However, another study has underlined that the physicochemical properties have only a minor role and the correlation between the surface properties and the bacterial adhesion were poor (Teixeira et al. 2008). The bacterial detachment is a main part of the biofilm life cycle (Wilson et al. 2004). The phenomenon is involved in the dissemination of infection and contamination in the healthcare and food settings (Nickel et al. 1994; Poulsen 1999). Moreover, Fux et al. (2004) reported that the mechanical biofilm detachment by flushing a colonized catheter provokes sepsis. The erosion of biofilm also results spontaneously, either in the detachment of single cells or clumps of thousands bacteria which contaminate and colonize other surfaces. Thus it is of importance to understand S. aureus phenotype changes related to bacterial growth under planktonic and biofilm states. Such investigations might yield important information regarding the virulence and the pathogenicity required for certain acquired human infections.

The purpose of the current work is to investigate the impact of $S$. aureus growth conditions on the physicochemical properties of the biofilm-detached-and the planktonic-cells and on their ability to adhere to the stainless steel (SS) and to the polycarbonate (PC). The planktonic and the biofilm cells were recovered from cultures incubated at different growth temperatures and ages commonly encountered in the medical environments. This work also investigated the effect of these growth conditions on the expression of some virulence factors, involved in the pathogenesis of S. aureus, and the cytotoxicity against HeLa cells.

\section{Materials and methods}

\section{Bacterial strains and culture conditions}

The bacterial strain used in this study was Staphylococcus aureus CIP 4.83. The strain was stored at $-80^{\circ} \mathrm{C}$ in Tryptic Soy Broth (TSB; Biokar Diagnostics, Pantin, France) containing $40 \%(\mathrm{v} / \mathrm{v})$ of glycerol. Pre-cultures were done by inoculating $100 \mu \mathrm{l}$ from frozen stock tubes into $5 \mathrm{ml}$ of TSB and then incubated at 20,30 or $37{ }^{\circ} \mathrm{C}$. The 30 and $37^{\circ} \mathrm{C}$ pre-cultures were incubated for $24 \mathrm{~h}$, whereas that of $20^{\circ} \mathrm{C}$ was incubated for $48 \mathrm{~h}$. The main cultures were done in $500-\mathrm{ml}$ sterile flasks containing $50 \mathrm{ml}$ of TSB.
The cultures of 20,30 and $37{ }^{\circ} \mathrm{C}$ were prepared by inoculating $10^{4} \mathrm{CFU} / \mathrm{ml}$ from the 20,30 and $37^{\circ} \mathrm{C}$ pre-culture tubes, respectively. The cultures were then incubated under shaking $(160 \mathrm{rpm})$ at 20,30 or $37^{\circ} \mathrm{C}$. The cultures were stopped at the late exponential phase.

\section{Coupons preparation}

The SS (304L, Equinox, Willems, France) and PC (Plexilux, Vaux-le-Pénil, France) slides were soaked in ethanol $95^{\circ}$ (Fluka, Sigma-Aldrich, Saint-Quentin-Fallavier, France) for an overnight and then rinsed twice with distilled water. Then the slides were soaked in $500 \mathrm{ml}$ of DDM ECO detergent (1\%) for $15 \mathrm{~min}$ at room temperature $\left(20^{\circ} \mathrm{C}\right)$ under agitation (ANIOS, Villeneuve d'Ascq, France). Slides were thoroughly rinsed five times, for one min under agitation, in $500 \mathrm{ml}$ of distilled water and three times in ultrapure water (Milli- $\mathrm{Q}^{\circledR}$ Academic, Millipore, Guyancourt, France) at $20^{\circ} \mathrm{C}$ to eliminate detergent residues. SS slides were air-dried and sterilized by autoclaving at $121{ }^{\circ} \mathrm{C}$ for $20 \mathrm{~min}$. PC slides were sterilized in the ethanol $95^{\circ}$ for $15 \mathrm{~min}$.

\section{Cell suspension preparation}

Staphylococcus aureus cells, grown at 20,30 and $37{ }^{\circ} \mathrm{C}$, were harvested by centrifuging cultures at $5000 \mathrm{~g}$ for $5 \mathrm{~min}$ at $20^{\circ} \mathrm{C}$. Bacteria were washed twice with $20 \mathrm{ml}$ of $100 \mathrm{mM}$ Potassium Phosphate Buffer (PPB; $\mathrm{pH} 7$ ) and finally resuspended in $20 \mathrm{ml}$ of PPB. In order to disperse cells, bacterial suspensions were subjected to a sonication at $37 \mathrm{kHz}$ for $5 \mathrm{~min}$ at $20{ }^{\circ} \mathrm{C}$ (Elmasonic $\mathrm{S} 60 \mathrm{H}$, Elma $\left.{ }^{\circledR}\right)$. The bacterial suspensions at $10^{8} \mathrm{CFU} / \mathrm{ml}$ were then prepared by adjusting the optical density to $\mathrm{OD}_{620 \mathrm{~nm}}=0.110 \pm 0.005$ using a Jenway 6320D UV/visible light spectrophotometer. Standardized cell suspensions $\left(10^{8} \mathrm{CFU} / \mathrm{ml}\right)$ were diluted tenfold for the biofilm formation and the bacterial adhesion assays $\left(10^{7} \mathrm{CFU} /\right.$ $\mathrm{ml})$.

\section{Biofilm formation assays}

Sterile coupons $(90 \times 90 \times 1 \mathrm{~mm})$ were placed in the horizontal position in cell culture dishes $(140 \mathrm{~mm}$ in diameter). The upper face of slides was covered by $12 \mathrm{ml}$ of 20,30 and $37^{\circ} \mathrm{C}$ cell suspensions $\left(10^{7} \mathrm{CFU} / \mathrm{ml}\right)$ and incubated at $20^{\circ} \mathrm{C}$ for $1 \mathrm{~h}$ to allow bacterial adhesion. Thereafter, the $12 \mathrm{ml}$ were removed and slides were gently rinsed twice with $12 \mathrm{ml}$ of PPB to remove loosely attached cells. The upper face of slides was covered by $12 \mathrm{ml}$ of TSB and the biofilm formation was started by incubating slides, at the same temperature of bacterial-cell-cultures (20, 30 or $37^{\circ} \mathrm{C}$ ), for an incubation duration of 24 or $48 \mathrm{~h}$. For the biofilm grown for $48 \mathrm{~h}$, the culture medium was changed after $24 \mathrm{~h}$ of biofilm growth, except for DNase, cell cytotoxicity, and siderophore quantification assays 
where the culture medium was not changed. After 24 and $48 \mathrm{~h}$, supernatants were removed and used for the DNase, the cell cytotoxicity, and siderophore quantification assays. The slides were rinsed twice with $12 \mathrm{ml}$ of PPB in order to remove loosely attached cells. Attached cells were then recovered into $10 \mathrm{ml}$ of PPB by surface scraping. Attached cells were harvested by centrifuging suspensions at $5000 \mathrm{~g}$ for $5 \mathrm{~min}$ at $20^{\circ} \mathrm{C}$ and then washed once with $20 \mathrm{ml}$ of PPB. In order to remove the biofilm matrix, attached cells were resuspended in $20 \mathrm{ml}$ of PPB and suspensions were sonicated at $37 \mathrm{kHz}$ for $5 \mathrm{~min}$ at $20{ }^{\circ} \mathrm{C}$. Finally, the attached cells were recovered in $20 \mathrm{ml}$ of PPB. The bacterial suspensions were adjusted to a cell concentration of $10^{7} \mathrm{CFU} / \mathrm{ml}$ for the bacterial adhesion assays.

\section{Adhesion assays}

The adhesion of planktonic cells was performed on both SS and PC discs $(41 \times 1 \mathrm{~mm})$. The adhesion of bacteria detached from biofilms grown on SS and PC was performed respectively on sterile SS and PC using the NEC Biofilm system (Abdallah et al. 2015). Sterile coupons of SS and PC were placed in the horizontal position in sterile NEC Biofilm system. The upper face of each slide was covered with $3 \mathrm{ml}$ of corresponding-cell-suspensions $\left(10^{7} \mathrm{CFU} / \mathrm{ml}\right)$ and statically incubated at $20^{\circ} \mathrm{C}$ for $60 \mathrm{~min}$ to allow bacterial adhesion. After $1 \mathrm{~h}$, the slides were removed using sterile forceps and rinsed twice by gently dipping into $30 \mathrm{ml}$ of PPB to remove excess liquid droplets and loosely attached cells. Cells were then stained for $15 \mathrm{~min}$ in the dark using Acridine Orange 0.01\% (w/v) (Sigma Aldrich, Saint-Quentin Fallavier, France) and then rinsed once by gently dipping in $30 \mathrm{ml}$ of ultrapure water. The attached cells were quantified using epifluorescence microscope (Nikon Optiphot-2 EFD3). A total of 30 fields per coupon was scanned and the stained cells were enumerated. The adhesion rates were presented as a number of bacteria per microscopic field. The results present the average of three independent experiments and in each experiment, two slides were studied.

\section{Microbial adhesion to solvents (MATS)}

The hydrophobicity and the electron donor (basic) or acceptor (acidic) properties of planktonic and biofilmdetached S. aureus were determined using the MATS method as described by Bellon-Fontaine et al. (1996). This method is based on the comparison of bacterial affinity to four solvents (Sigma Aldrich, Saint-Quentin Fallavier, France) with different physicochemical properties. The following pairs of solvents were used: chloroform (electron acceptor solvent)/hexadecane (a nonpolar solvent); ethyl acetate (an electron donor solvent)/decane (a nonpolar solvent). Due to the similar Lifshitz-van der
Waals components of the surface tension in each pair of solvents, differences between the affinities to solvents would indicate the electron donor and electron acceptor characters of the bacterial surfaces. The affinity of cells to hexadecane was used as a measure of cell surface hydrophobicity.

Experimentally, bacterial suspensions of $10^{8} \mathrm{CFU} / \mathrm{ml}$ were prepared in PPB by adjusting the optical density to $\mathrm{OD}_{400 \mathrm{~nm}}=0.8\left(\mathrm{~A}_{0}\right)$. Then $2.4 \mathrm{ml}$ of each bacterial suspension were added to $0.4 \mathrm{ml}$ of each solvent and then vortexed for $90 \mathrm{~s}$. The mixture was allowed to stand for $30 \mathrm{~min}$ to ensure the complete separation of the two phases. Then the optical density of the aqueous phase $\left(A_{1}\right)$ was measured at $400 \mathrm{~nm}$ using a Jenway $6320 \mathrm{D}$ UV/visible light spectrophotometer. The affinity of cells to each solvent was subsequently calculated using the following equation: Affinity $\%=\left[1-\left(\mathrm{A}_{1} / \mathrm{A}_{0}\right)\right] \times 100$. The results represent the average of three independent experiments.

\section{Measurement of zeta potential}

The electrostatic properties of $S$. aureus were determined by measuring the zeta potential (ZP) which is derived from the electrophoretic mobility, using the HelmotzSmoluchowski equation (Bayoudh et al. 2009). The electrophoretic mobility of bacteria cells suspended in PPB was measured using a laser Zeta Compact zetameter (CAD Instruments, Les Essarts-le-Roi, France), by tracking bacteria with a coupled device camera, under an electric field of $80 \mathrm{~V}$. Each bacterial suspension was diluted in PPB to obtain about 70 bacteria per reading. A $1 \mathrm{mM}$ of the $\mathrm{KNO}_{3}$ solution was used as the electrolyte and $\mathrm{KOH}$ $(1 \mathrm{mM})$ and $\mathrm{HNO}_{3}(1 \mathrm{mM})$ were used to adjust the $\mathrm{pH}$ to 7.2 (Sigma-Aldrich, Saint-Quentin-Fallavier, France). For each sample, the ZP measurements were repeated five times. Each experiment was performed in duplicate by using two independent cultures.

\section{Cytotoxicity assay}

Supernatants were recovered from biofilms grown on SS and PC, and planktonic cultures, after 24 and $48 \mathrm{~h}$ of incubation. Supernatants of planktonic and biofilm cultures, grown at 20,30 and $37^{\circ} \mathrm{C}$ for 24 and $48 \mathrm{~h}$, were collected and the $\mathrm{pH}$ was adjusted to $7.2 \pm 0.05$ using $1 \mathrm{M}$ hydrochloric acid $(\mathrm{HCl})$ (Sigma-Aldrich, Saint-Quentin-Fallavier, France). Next, supernatants were filtered through sterile $0.2 \mu \mathrm{m}$ Millipore filters. Both planktonic and sessile $S$. aureus supernatants were diluted after being adjusted to similar cell densities based on optical density $(620 \mathrm{~nm})$ measurements. The HeLa cell line, derived from cervical carcinoma from a 31-yearold female $\left(\mathrm{ATCC}^{\circledR} \mathrm{CCL}-2^{\mathrm{TM}}, \mathrm{ECACC}\right.$ ), were cultured and maintained in Dulbecco's Modified Eagle's medium 
(DMEM, Gibco ${ }^{\circledR}$, Thermo Fisher Scientific, Illkirch, France) supplemented with $10 \%$ Fetal Bovine Serum (FBS, Gibco ${ }^{\circledR}$ ) and $1 \%$ penicillin-streptomycin $\left(\right.$ Gibco $\left.^{\circledR}\right)$ in a humidified incubator at $37{ }^{\circ} \mathrm{C}$ and $5 \% \mathrm{CO}_{2}$. Cells were seeded at a cell density of $10^{4}$ cells/well in a 96-well plate and grown for $48 \mathrm{~h}$ before assay. For cytotoxicity assay, the culture medium was replaced with $100 \mu \mathrm{l}$ of $10 \%$ FBS or TSB ( $\mathrm{pH}$ 7.2) for the negative control or with $100 \mu \mathrm{l}$ of $S$. aureus culture supernatants. After $3 \mathrm{~h}$ of contact, the mixture was aspirated and cells were washed with Phosphate Buffered Saline (PBS, pH 7.4, ThermoFisher Scientific, Illkirch, France). The cell viability was evaluated using Cell Counting Kit-8 (CCK-8, Sigma-Aldrich, Saint-Quentin-Fallavier, France) assay. Briefly, $10 \mu \mathrm{l}$ of the CCK-8 solution were added to each well containing $100 \mu \mathrm{l}$ of DMEM with $10 \%$ FBS and the plate were incubated for $1 \mathrm{~h}$ in the humidified incubator. The absorbance of each well at $450 \mathrm{~nm}$ was measured using a microplate reader (PHERA star FS, BMG LABTECH GmbH, Germany). The mean absorbance value of cells non-treated with supernatants was taken as $100 \%$ cellular viability. The results represent the average of three independent experiments and each experiment was done in triplicate.

\section{Deoxyribonuclease (DNase) activity assay}

Bacterial supernatants were collected as described above. Enzyme production was tested on DNA agar (Thermo Fisher Scientific, Illkirch, France) by the deposition of $100 \mu \mathrm{l}$ of each supernatant in $6 \mathrm{~mm}$ diameter well. Supernatant volume was allowed to diffuse for $2 \mathrm{~h}$ at $4{ }^{\circ} \mathrm{C}$. The plates were incubated at $37{ }^{\circ} \mathrm{C}$ overnight. After incubation, wells were flooded with $1 \mathrm{M} \mathrm{HCl}$. DNase production was identified by a halo zone of clearance (DNA degradation) around the supernatant deposition well. The halo zone diameters correlated with the DNase activity in the corresponding supernatant. The results represent the average of three independent experiments and each experiment was done in duplicate.

\section{Quantitative spectrophotometric assay for siderophore production}

The siderophore quantification of $S$. aureus-culturesupernatants is based on Chrome Azurol Sulphonate (CAS assay) according to Schwyn and Neilands (1987). All reagents were purchased from Fluka Sigma-Aldrich (Saint-Quentin-Fallavier, France). Briefly, in order to prepare the CAS assay solution, $6 \mathrm{ml}$ of $10 \mathrm{mM}$ hexadecyltrimethylammonium bromide, $1.5 \mathrm{ml}$ of iron (III) solution $\left(1 \mathrm{mM} \mathrm{FeCl}{ }_{3} 6 \mathrm{H}_{2} \mathrm{O}, 10 \mathrm{mM} \mathrm{HCl}\right), 7.5 \mathrm{ml}$ of $2 \mathrm{mM}$ aqueous CAS solution and $20 \mathrm{ml}$ of $2.5 \mathrm{mM}$ piperazine buffer in $\mathrm{H}_{2} \mathrm{O}(\mathrm{pH} 5)$ were mixed in a 100 -ml volumetric flask which was then filled with water to afford
$100 \mathrm{ml}$ of CAS assay solution. Then, $100 \mathrm{mg}$ of 5 -sulfosalicylic were added to the CAS assay solution and stored in the dark.

In order to quantify the siderophores, $0.5 \mathrm{ml}$ of the culture supernatant was mixed with $0.5 \mathrm{ml}$ from the prepared CAS assay solution. After $1 \mathrm{~h}$ of incubation at $20{ }^{\circ} \mathrm{C}$, the absorbance $\left(\mathrm{A}_{630 \mathrm{~nm}}\right)$ is measured by a Jenway 6320D UV/visible light spectrophotometer. The CASiron complex color changes from dark blue to orange after the iron chelation by siderophores. The TSB was used as the blank (reference sample). The percentage of siderophore units was estimated as the proportion of CAS color shift using the formula [( $\mathrm{Ar}-\mathrm{As}) /$ $(\mathrm{Ar})] \times 100$, where $\mathrm{Ar}$ is the $\mathrm{A}_{630 \mathrm{~nm}}$ of the reference sample (TSB + CAS assay solution + shuttle solution) and As is the $\mathrm{A}_{630 \mathrm{~nm}}$ of the sample (supernatant + CAS assay solution + shuttle solution).

\section{Statistics}

The results are presented as mean values and their standard error of the mean. Data analysis was performed using Sigma Plot 11.0 (Systat Software Inc.), using one-way ANOVA (Tukey's method) to determine the significance of differences. Results were considered significant at a $P$ value of $<0.05$.

\section{Results \\ Effect of growth conditions on the zeta potential of biofilm-detached and planktonic S. aureus cells}

This investigation aimed to study the electronegativity of planktonic and biofilm-detached cells in response to different bacterial growth temperatures $\left(20,30\right.$ and $\left.37{ }^{\circ} \mathrm{C}\right)$ and incubation durations ( 24 and $48 \mathrm{~h}$ ). For the biofilm formation, two abiotic surfaces, the SS and the PC were used. Figure 1 presents the zeta potential (ZP) values of bacterial surfaces as a function of $S$. aureus growth conditions. The results indicated that $S$. aureus cells were negatively charged, with negative ZP values, whatever the growth conditions (Fig. 1).

Figure 1a showed that the growth temperature and the incubation duration had a significant effect on the ZP of planktonic cells $(P<0.05)$. The increase of growth temperature from 20 to $37{ }^{\circ} \mathrm{C}$ significantly increased the $\mathrm{ZP}$ of the $24 \mathrm{~h}$ planktonic cells from -26.3 to $-13.6 \mathrm{mV}$ $(P<0.05)$ and the $\mathrm{ZP}$ of $48 \mathrm{~h}$ planktonic cells from -22.7 to $-18.7 \mathrm{mV}(P<0.05)$ (Fig. 1a). When cells were grown at $20^{\circ} \mathrm{C}$, the results underlined that the increase of incubation time from 24 to $48 \mathrm{~h}$ increased by 1.2 -fold the $\mathrm{ZP}$ of planktonic cells $(P<0.05)$. However, the increase of the incubation duration of $37^{\circ} \mathrm{C}$ planktonic cultures from 24 to $48 \mathrm{~h}$ significantly decreased by 1.4 -fold the ZP of planktonic cells $(P<0.05)$. 

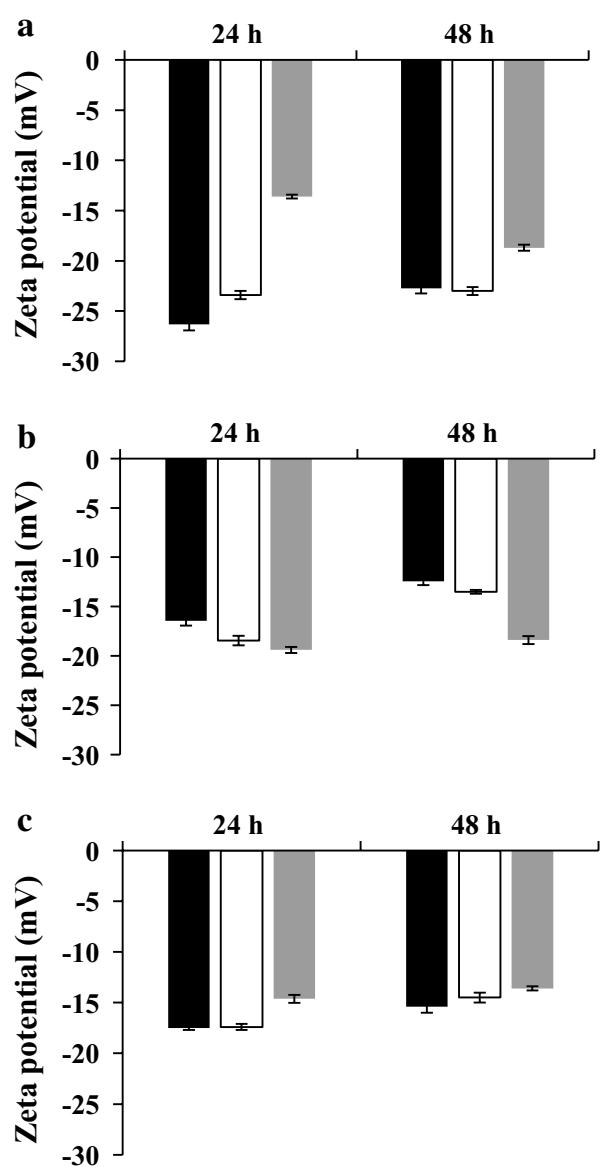

Fig. 1 Zeta potential of planktonic and biofilm detached Staphylococcus aureus cells. Cell cultures were grown at $20^{\circ} \mathrm{C}$ (black square), $30^{\circ} \mathrm{C}$ (white square) and $37^{\circ} \mathrm{C}$ (grey square), for 24 and 48 h. Planktonic cells (a), cells detached from biofilm grown on polycarbonate (b), cells detached from biofilms grown on stainless steel (c)

Furthermore, the results showed in Fig. 1 indicated that planktonic cells were significantly more negatively charged than their biofilm-detached counterparts whatever the studied conditions $(P<0.05)$, except for planktonic cells grown at $37{ }^{\circ} \mathrm{C}$ for $24 \mathrm{~h}$ where the electronegativity of planktonic cell surfaces was lower than that of $24 \mathrm{~h}$ biofilm-detached cells $(P<0.05)$. In addition, our findings underlined that the abiotic surface type had a significant effect on the electronegativity of the biofilmdetached cells (Fig. 1b, c). When the growth temperature increased from 20 to $37^{\circ} \mathrm{C}$, the $\mathrm{ZP}$ of $24 \mathrm{~h}$ and $48 \mathrm{~h}$ Polycarbonate-Biofilm-Detached-Cells (PCBDCs) significantly decreased from -16.4 to $-19.4 \mathrm{mV}$ and from -12.4 to $-18.4 \mathrm{mV}$, respectively $(P<0.05)$ (Fig. $1 \mathrm{~b})$. The increase of incubation duration from 24 to $48 \mathrm{~h}$ had only a significant effect on the electronegativity of PCBDCs grown at 20 and $30{ }^{\circ} \mathrm{C}$. The increase of incubation duration of the biofilm cultures from 24 to $48 \mathrm{~h}$ increased by 1.4-fold the ZP of 20 and $30{ }^{\circ} \mathrm{C}$ PCBDCs $(P<0.05)$ (Fig. 1b). The stainless steel-biofilm-detached-cells (SSBDCs) showed an opposite electronegativity trend regarding the effect of growth temperature. The Fig. 1c showed that the increase of the biofilm growth temperature from 20 to $37{ }^{\circ} \mathrm{C}$ significantly increased the ZP of SSBDCs by 1.2-fold $(P<0.05)$ whatever the incubation durations (Fig. 1c).

\section{Effect of growth conditions on the cell surface hydrophobicity and electron donor/acceptor characters of biofilm-detached and planktonic S. aureus cells}

This study investigated the physicochemical surface properties of planktonic and biofilm-detached S. aureus cells, using the microbial adhesion to solvents (MATS), in response to different incubation durations ( 24 and $48 \mathrm{~h}$ ), growth temperatures $\left(20,30\right.$ and $\left.37{ }^{\circ} \mathrm{C}\right)$ and abiotic surfaces (SS and PC). The results related to the hydrophobicity (affinity to hexadecane) and the acceptor/donor character of planktonic and biofilm-detached $S$. aureus cells are shown in Fig. 2 and Table 1.

The results underlined that the increase of growth temperature of $S$. aureus significantly increased the hydrophobic character of planktonic cell surfaces $(P<0.05)$ (Fig. 2a, b). When cells were grown at $20^{\circ} \mathrm{C}$, the increase of the incubation duration from 24 to $48 \mathrm{~h}$ significantly increased the affinity of planktonic cells to hexadecane from 61.9 to $73.2 \%(P<0.05)$ (Fig. $2 \mathrm{a}, \mathrm{b})$. However, the surface hydrophobicity of planktonic cells grown at 30 and $37^{\circ} \mathrm{C}$ was not influenced by the increase of the incubation duration of $S$. aureus cultures $(P>0.05)$. Table 1 showed that planktonic cells have low relative electron acceptor character whatever the growth conditions. However, the electron donor character of planktonic cells grown for $24 \mathrm{~h}$ decreased from 31.2 to 0.7 with the increase of growth temperature from 20 to $37^{\circ} \mathrm{C}$. Similar results were observed for planktonic cells grown for $48 \mathrm{~h}$ (Table 1). Our findings also showed that, in addition to the incubation duration and the growth temperature, the surface type, had a significant effect on the hydrophobicity as well as the acceptor/donor character of $S$. aureus biofilms-detached cells (Fig. 2a, b). After an incubation duration of $24 \mathrm{~h}$, the surface hydrophobicity of SSBDCs decreased with the increase of the biofilm growth temperature. The affinity of $24 \mathrm{~h}$ SSBDCs to hexadecane decreased from 96 to $77 \%$ when the biofilm growth temperature increased from 20 to $37{ }^{\circ} \mathrm{C}(P<0.05)$ (Fig. 2a). However, an opposite profile was observed for cells recovered from biofilms grown on the SS for $48 \mathrm{~h}$. The affinity of $48 \mathrm{~h} \mathrm{SSBDCs}$ to hexadecane increased from 80 to $98 \%$ when the biofilm growth temperature increased 

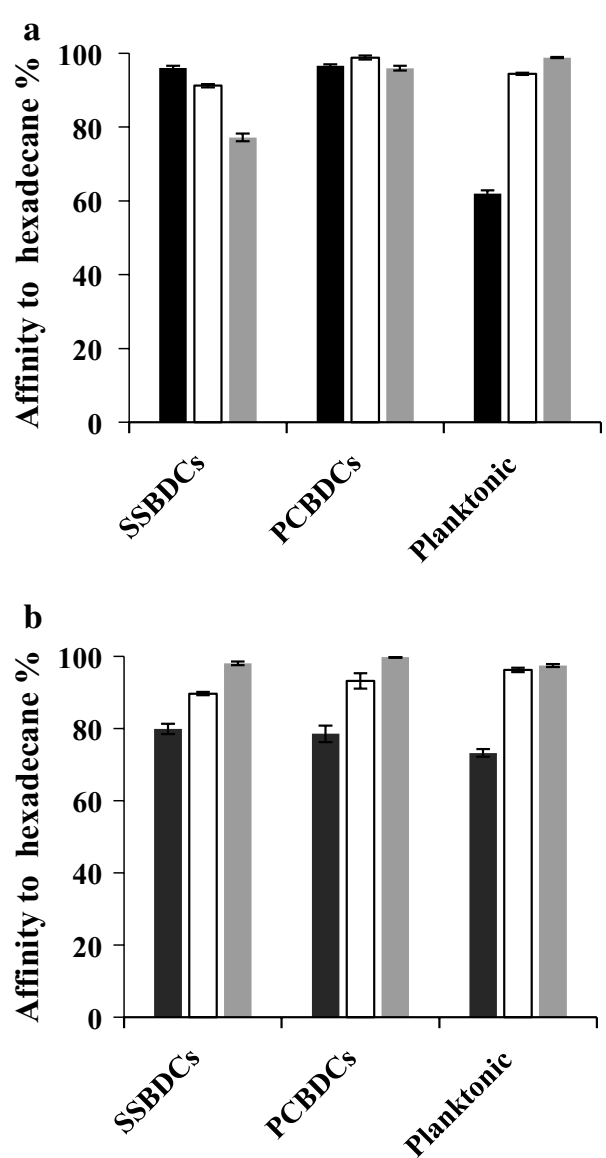

Fig. 2 Affinity of planktonic and biofilm detached Staphylococcus aureus cells to hexadecane. Cells grown, at $20^{\circ} \mathrm{C}$ (black square), $30^{\circ} \mathrm{C}$ (white square) and $37^{\circ} \mathrm{C}$ (grey square). SSBDCs represents the stainless steel-biofilm-detached-cells. PCBDCs represents the polycarbonate-biofilm-detached-cells. Cells grown during $24 \mathrm{~h}(\mathbf{a})$ and $48 \mathrm{~h}(\mathbf{b})$ from 20 to $37{ }^{\circ} \mathrm{C}$ (Fig. 2b). The affinity of $48 \mathrm{~h}$ PCBDCs to the hexadecane increased from 78 to $99 \%(P<0.05)$ when the biofilm growth temperature increased from 20 to $37^{\circ} \mathrm{C}$ (Fig. 2b). Furthermore, the results showed that the electron donor characters of $24 \mathrm{~h}$ SSBDCs increased from 1.9 to 21.6 with the increase of the biofilm growth temperature from 20 to $37^{\circ} \mathrm{C}$. The electron donor character of $24 \mathrm{~h}$ PCBDCs increased from 2.2 to 4 when the growth temperature increased from 20 to $37^{\circ} \mathrm{C}$ (Table 1 ). After $48 \mathrm{~h}$ of incubation, the electron donor character of SSBDCs and PCBDCs decreased from 18.6 to 1.3 when the growth temperature of biofilms increased from 20 to $37^{\circ} \mathrm{C}$ whatever the surface type of the biofilm formation (Table 1). Table 1 also showed that the increase of biofilm growth temperature from 20 to $37{ }^{\circ} \mathrm{C}$ significantly decreased the electron acceptor character of $24 \mathrm{~h}$ and $48 \mathrm{~h}$ SSBDCs from 17.4 to -22.3 and from 7.2 to -17.7 , respectively (Table 1). The results of Table 1 also showed that PCBDCs presented low relative electron acceptor character whatever the growth conditions.

When cells were grown at $20^{\circ} \mathrm{C}$, the result showed that the electron donor characters of $24 \mathrm{~h}$ and 48 planktonic cells were 16 and 1.3-fold higher than those of 24 and $48 \mathrm{~h}$ biofilm-detached cells, respectively (Table 1). However, the electron donor character of SSBDCs, grown at 30 and $37^{\circ} \mathrm{C}$, was twofold higher than that of their planktonic counterparts whatever the biofilm incubation duration, except for the $24 \mathrm{~h}$ SSBDCs grown at $37{ }^{\circ} \mathrm{C}$ where the electron donor character was of 30 -fold higher. The results also showed that the electron donor characters of 30 and $37^{\circ} \mathrm{C}$ SSDBCs were significantly higher than that of their PCBDCs counterparts whatever the biofilm incubation duration.

Table 1 Electron donor/acceptor character of biofilm-detached and planktonic Staphylococcus aureus cells, grown at 20, 30 and $37^{\circ} \mathrm{C}$, during 24 and $48 \mathrm{~h}$

\begin{tabular}{|c|c|c|c|c|c|c|c|}
\hline & \multirow[t]{2}{*}{$\mathrm{T}^{\circ} \mathrm{C}^{\mathrm{C}}$} & \multicolumn{3}{|c|}{ Electron donor ${ }^{\mathrm{a}}$} & \multicolumn{3}{|c|}{ Electron acceptor ${ }^{\mathbf{b}}$} \\
\hline & & SSBDCs $^{d}$ & $\mathrm{PCBDCs}^{\mathbf{e}}$ & Planktonic & SSBDCs & PCBDCs & Planktonic \\
\hline \multirow[t]{3}{*}{$24 \mathrm{~h}$} & 20 & $1.9 \pm 0.1$ & $2.2 \pm 0.5$ & $31.2 \pm 1.1$ & $17.4 \pm 0.5$ & $-49.6 \pm 3.2$ & $3.9 \pm 0.6$ \\
\hline & 30 & $7.8 \pm 0.6$ & $0.9 \pm 0.7$ & $4.8 \pm 0.5$ & $-1.5 \pm 0.2$ & $-19.5 \pm 2.4$ & $-31.8 \pm 0.2$ \\
\hline & 37 & $21.6 \pm 0.6$ & $4 \pm 0.6$ & $0.7 \pm 0.1$ & $-22.3 \pm 0.9$ & $-17.9 \pm 0.7$ & $-63.6 \pm 0.2$ \\
\hline \multirow[t]{3}{*}{$48 \mathrm{~h}$} & 20 & $18.6 \pm 1.6$ & $18.6 \pm 2.2$ & $25.2 \pm 0.5$ & $7.2 \pm 1.3$ & $-23.5 \pm 1.8$ & $-70.3 \pm 2.8$ \\
\hline & 30 & $9.8 \pm 0.2$ & $6.2 \pm 1.8$ & $3.7 \pm 0.7$ & $7.1 \pm 0.3$ & $-22.6 \pm 2.7$ & $-38.5 \pm 2.6$ \\
\hline & 37 & $1.3 \pm 0.3$ & $-1 \pm 0.2$ & $0.6 \pm 0.1$ & $-17.7 \pm 0.2$ & $-14.3 \pm 3.6$ & $-25.4 \pm 1.7$ \\
\hline
\end{tabular}

\footnotetext{
a The differences between the chloroform and hexadecane affinities of cells suspended in $100 \mathrm{mM} \mathrm{PPB} \mathrm{(pH} \mathrm{7)} \mathrm{presents} \mathrm{the} \mathrm{electron} \mathrm{donor} \mathrm{character}$

b The differences between the ethyl acetate and decane affinities of cells suspended in $100 \mathrm{mM} \mathrm{PPB} \mathrm{(pH} \mathrm{7)} \mathrm{presents} \mathrm{the} \mathrm{electron} \mathrm{acceptor} \mathrm{character}$

${ }^{\mathrm{C}} \mathrm{T}^{\circ} \mathrm{C}$ represents the growth temperature

d SSBDCs represents the stainless steel-biofilm-detached-cells

e PCBDCs represents the polycarbonate-biofilm-detached-cells
} 
Effect of growth conditions on the adhesion of biofilm-detached and planktonic S. aureus cells to stainless steel and polycarbonate

This investigation aimed to study the effect of the $S$. aureus growth conditions on the adhesion behavior of planktonic S. aureus cells on SS and PC. The adhesion assays have been done using planktonic cells recovered from cultures grown under different growth temperatures $\left(20,30\right.$ and $\left.37^{\circ} \mathrm{C}\right)$ and durations $(24$ and $48 \mathrm{~h})$.

Our results showed that the increase of the growth temperature of $S$. aureus from 20 to $37{ }^{\circ} \mathrm{C}$ slightly increased by 1.2-fold the adhesion of planktonic cells on the SS whatever the incubation duration $(P>0.05)$ (Fig. 3a). The adhesion experiments performed on the PC showed that the adhesion rate of $24 \mathrm{~h}$ planktonic cells increased by 1.2 -fold when the growth temperature of S. aureus increased from 20 to $37^{\circ} \mathrm{C}(P>0.05)$ (Fig. 3b). Figure $3 \mathrm{a}, \mathrm{b}$ showed that the adhesion rate of 24 and $48 \mathrm{~h}$ planktonic cells was respectively $1.4-(P<0.05)$ and $1.2-$ fold $(P>0.05)$ higher on the SS than on the PC whatever the growth temperature, except for the planktonic $S$. aureus cells grown for $48 \mathrm{~h}$ at $20^{\circ} \mathrm{C}$ where the adhesion rates were similar on both studied abiotic surfaces.

This study also investigated the adhesion behaviour of biofilm-detached cells, recovered from biofilms grown under different incubation temperatures $(20,30$ and $37{ }^{\circ} \mathrm{C}$ ), durations ( 24 and $48 \mathrm{~h}$ ) and surface types (SS and $\mathrm{PC})$, on the SS and PC. For this study, the adhesion of SSBDCs and PCBDCs was investigated respectively on the SS and the PC.

The results underlined that the abiotic surface type and the temperature of the biofilm formation had an effect on the adhesion behavior of SSBDCs on the SS. Figure 3c showed that the increase of the biofilm growth temperature from 20 to $37{ }^{\circ} \mathrm{C}$ increased by 1.3 -fold the adhesion rate of 24 and $48 \mathrm{~h}$ SSBDCs on theSS (Fig. 3c). However, the Fig. 3d showed that neither the time nor the temperature of biofilm growth had a significant effect on the adhesion rate of PCBDCs on the PC $(P>0.05)$. Furthermore, our data showed that the adhesion rate of SSDBCs
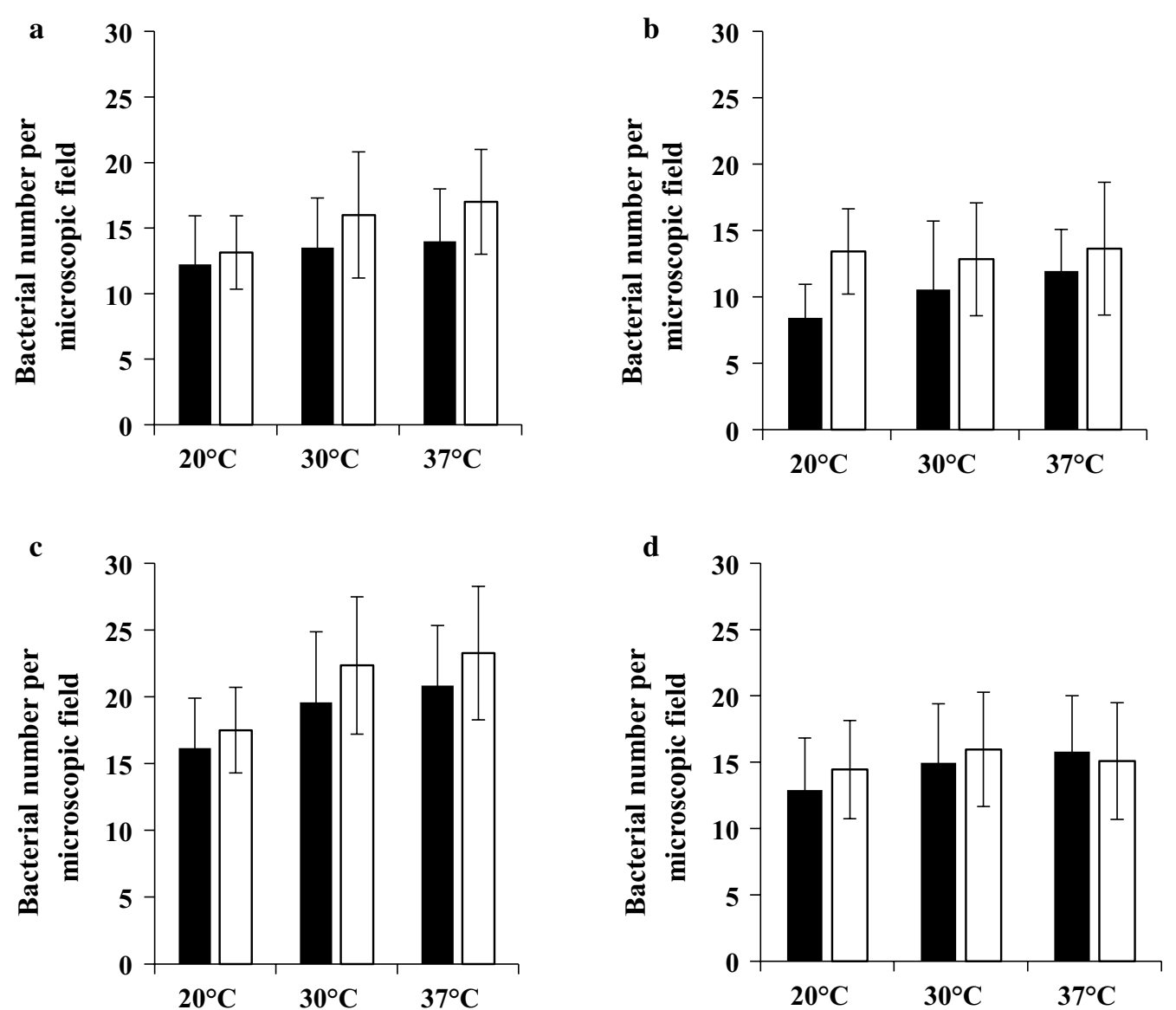

Fig. 3 Adhesion of planktonic and biofilm-detached Staphylococcus aureus cells on stainless steel and polycarbonate. Cell cultures were grown at 20, 30 and $37^{\circ} \mathrm{C}$, during $24 \mathrm{~h}$ (black square) and $48 \mathrm{~h}$ (white square). Planktonic cells adhesion on stainless steel (a) and polycarbonate (b). Adhesion of stainless steel-biofilm-detached-cells on stainless steel 24 (c) and polycarbonate-biofilm-detached-cells on polycarbonate (d) 
on the SS was 1.3-fold higher than the adhesion rate of their PCBDCs counterparts on the PC whatever the studied conditions (Fig. 3c, d). Moreover, Fig. 3a, c showed that the bacterial adhesion rate of SSBDCs on the SS was 1.4-fold higher than the adhesion rate of their planktonic counterparts on the same surface whatever the growth temperature and incubation durations $(P<0.05)$. The adhesion rate of $24 \mathrm{~h}$ PCBDCs on the PC was 1.5-fold higher than that of $24 \mathrm{~h}$ planktonic cells on the same surface whatever the growth temperature $(P<0.05)$. However, the adhesion rates of $48 \mathrm{~h} \mathrm{PCBDCs}$ on the PC was similar to that of $48 \mathrm{~h}$ planktonic cells on the same surface whatever the growth temperature $(P>0.05)$ (Fig. 3b, d).

\section{Effect of growth conditions on the production of DNase by $S$. aureus biofilm and planktonic cultures}

The assessment of the nuclease activity was realized on supernatants recovered from planktonic cultures and biofilm grown on SS and PC at different growth temperatures $\left(20,30\right.$ and $\left.37^{\circ} \mathrm{C}\right)$ and incubation durations (24 and $48 \mathrm{~h})$. The TSB has been used as a negative control and the results showed that it had no DNase activity (data not shown).

The results showed that the DNase activity of the planktonic-culture-supernatants (PCSs) seems to be dependent on the temperature and the incubation duration of growth. The increase of the growth temperature from 20 to $30{ }^{\circ} \mathrm{C}$ significantly $(P<0.05)$ rose the DNase activity of PCSs by twofold whatever the incubation duration (Fig. 4a). When the incubation temperature increased from 20 to $37^{\circ} \mathrm{C}$, the DNase activity of 24 and $48 \mathrm{~h}$ PCSs increased respectively by 1.2 - and 1.8fold $(P>0.05)$ (Fig. 4a). The results also showed that the increase of the incubation duration of planktonic cultures from 24 to $48 \mathrm{~h}$ significantly increased the DNase activity of 30 and $37{ }^{\circ} \mathrm{C}$ PCSs respectively by 1.2 - and 1.6-fold $(P<0.05)$ (Fig. 4a).

Our results also showed that the abiotic surface type had a significant effect on the DNase production by sessile $S$. aureus cells and this effect is dependent on the duration and the temperature of biofilm growth. When biofilm growth temperature increased from 20 to $37^{\circ} \mathrm{C}$, the DNase activity of supernatants recovered from $24 \mathrm{~h}$ and $48 \mathrm{~h}$ SS-biofilms increased respectively by 1.9 - and 1.2 -fold $(P<0.05)$ (Fig. $4 \mathrm{c})$. The increase of the PC biofilm incubation temperature from 20 to $37{ }^{\circ} \mathrm{C}$ increased the DNase activity of 24 and $48 \mathrm{~h}$ biofilm-cultures-supernatants (BCSs) respectively by 1.4- and 1.2-fold (Fig. 4b). Furthermore, the results showed that the increase of the incubation duration from 24 to $48 \mathrm{~h}$ increased the DNase activity of 20,30 and $37{ }^{\circ} \mathrm{C}$ BCSs respectively by $1.6,1.1$ and 1.4-fold when the biofilms were grown on the PC

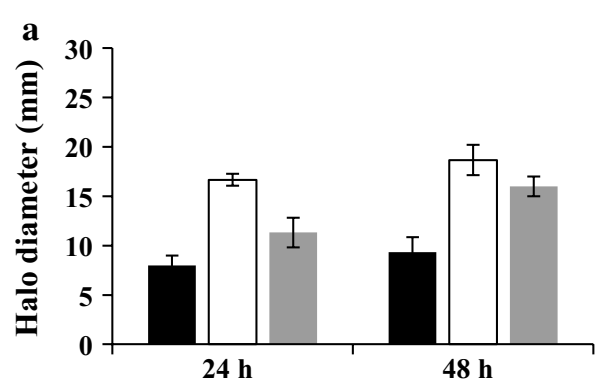

b
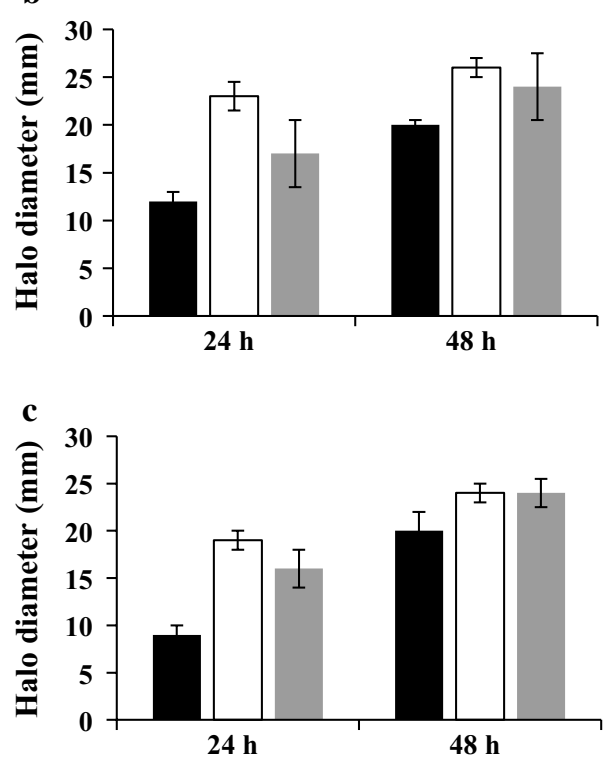

Fig. 4 DNase activity in supernatants recovered from Staphylococcus aureus planktonic and biofilm cultures. Cell cultures were grown at $20^{\circ} \mathrm{C}$ (black square), $30^{\circ} \mathrm{C}$ (white square) and $37^{\circ} \mathrm{C}$ (grey square), during 24 and $48 \mathrm{~h}$. Planktonic cultures (a), biofilms grown on polycarbonate $(\mathbf{b})$ and biofilms grown on stainless steel $(\mathbf{c})$

$(P<0.05)$ and respectively by $2.2,1.2$ and 1.5 -fold when the biofilms were grown on the SS $(P<0.05)$ (Fig. 4c). Furthermore, our data underlined that BCSs of $S$. aureus seem to have higher DNase activity than that of PCSs whatever the studied conditions $(P<0.05)($ Fig. $4 \mathrm{a}-\mathrm{c})$.

\section{Effect of growth conditions on the cytotoxicity of $S$. aureus} biofilm and planktonic cultures

The planktonic and biofilm culture supernatants, used for the DNase analysis, have been used to test their cytotoxic effects against HeLa cells. This study willed to evaluate the supernatant cytotoxicity of $S$. aureus cells as a function of their growth conditions. The viability of HeLa cells, after an incubation of $3 \mathrm{~h}$ with appropriate supernatants, is shown in Fig. 5. The TSB has been used as a negative control. The results showed that TSB, used as a negative control, slightly reduced the viability of HeLa cells by $5 \%$ whatever the studied conditions (Fig. $5 a-c$ ). 
Our findings also underlined that planktonic and biofilm-culture supernatants had a significant effect on HeLa cells viability $(P<0.05)$ and this effect seems dependent on the temperature and the incubation duration of planktonic cultures. The results showed that the PCSs did not affect the HeLa cell viability when cultures are incubated at 20 and $30{ }^{\circ} \mathrm{C}$ for 24 and $48 \mathrm{~h}$ (Fig. 5a). However, the $37{ }^{\circ} \mathrm{C}$ PCSs reduced by twofold $(P<0.05)$ the HeLa cell viability whatever the incubation duration of planktonic cultures (Fig. 5a).

Figure $5 \mathrm{~b}, \mathrm{c}$ also showed that the surface type of the biofilm formation had a significant effect on the cytotoxicity of the BCSs $(P<0.05)$. After an incubation time of $24 \mathrm{~h}$, the cytotoxicity of PC and the SS-BCSs significantly
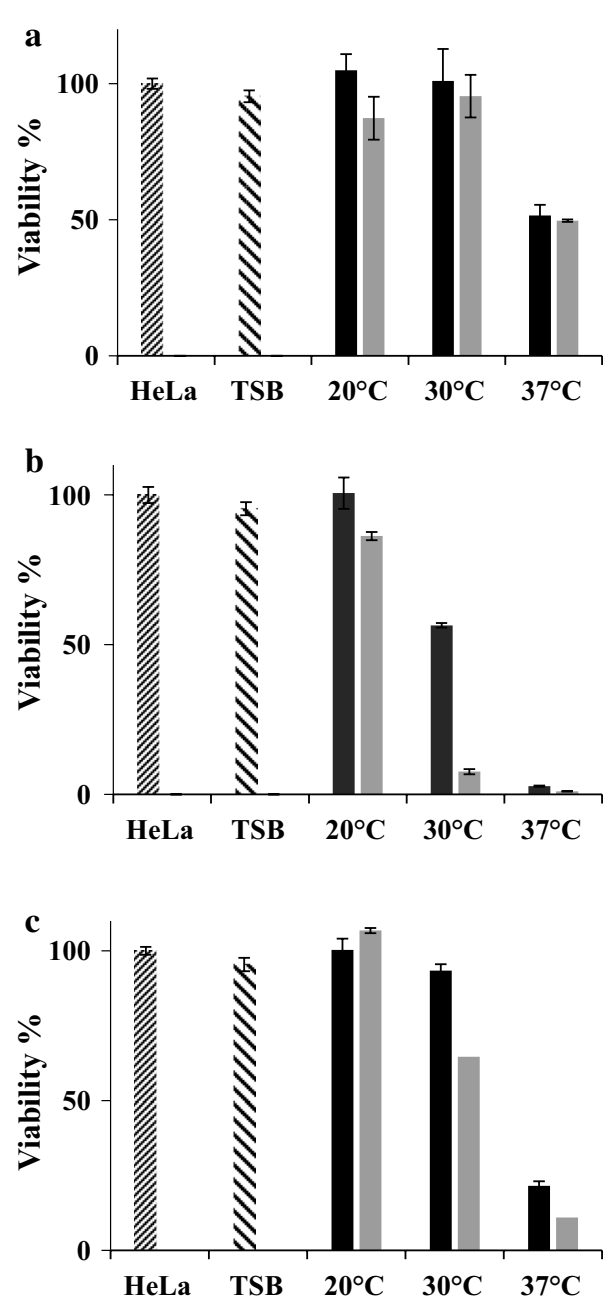

Fig. 5 Cytotoxicity of Staphylococcus aureus supernatants recovered from planktonic and biofilm cultures. Cell cultures were grown at 20,30 and $37^{\circ} \mathrm{C}$, during $24 \mathrm{~h}$ (black square) and $48 \mathrm{~h}$ (grey square). Planktonic cells (a), biofilms grown on polycarbonate $(\mathbf{b})$ and biofilms grown on stainless steel $(\mathbf{c})$ decreased the viability of HeLa cells respectively by 36.4- and 4.6-fold when the biofilm growth temperature increased from 20 to $37{ }^{\circ} \mathrm{C}(P<0.05)$ (Fig. 5b, c). Similar data were observed for the $48 \mathrm{~h} \mathrm{BCSs}$ (Fig. 5b, c). At $20{ }^{\circ} \mathrm{C}$, the biofilm supernatants have not shown a significant cytotoxic effect against HeLa cells whatever the studied conditions (Fig. 5a-c). Furthermore, the PC-BCSs seem to be more cytotoxic than their SS and planktonic counterparts (Fig. 5a-c). After 24 h of incubation, the supernatants of 20,30 and $37{ }^{\circ} \mathrm{C}$ PC-biofilms was respectively 1.3-, 1.2- and 3-fold more cytotoxic than that of their SS counterparts (Fig. 5b, c). After $24 \mathrm{~h}$, the cytotoxicity levels of the 20,30 and $37{ }^{\circ} \mathrm{C}$ PC-BCSs was 1.3, 2 and 24-fold higher $(P<0.05)$ than those of 20,30 and $37{ }^{\circ} \mathrm{C}$ planktonic supernatants, respectively (Fig. $5 \mathrm{a}$, b). This trend was more pronounced when comparing the supernatant cytotoxicity of $48 \mathrm{~h}$ aged biofilm to the $48 \mathrm{~h}$ planktonic ones $(P<0.05)$ (Fig. 5a, b). In fact, the cytotoxicity of the PC and SS culture supernatants were respectively 57 and fivefold higher than that of planktonic cultures (Fig. 5a-c).

\section{Effect of growth conditions on siderophore production by $S$. aureus biofilm and planktonic cultures}

The goal here is to investigate the effect of incubation duration, growth temperature and surface type on the siderophore production by planktonic and biofilm $\mathrm{S}$. aureus cells (Fig. 6). The results of Fig. 6a showed no detectable siderophore production when planktonic cells were grown at 20 and $30{ }^{\circ} \mathrm{C}$ whatever the incubation durations. However, the planktonic cells grown at $37{ }^{\circ} \mathrm{C}$ exhibited $11 \%$ of siderophore units whatever the incubation duration of planktonic cultures (Fig. 6a). Our findings also showed that the surface type, the growth temperature, and the incubation duration had a significant effect $(P<0.05)$ on siderophores production by sessile $S$. aureus cells (Fig. 6b, c). When grown on the SS, the increase of the biofilm growth temperature from 20 to $37{ }^{\circ} \mathrm{C}$ significantly increased the percentage of siderophores units of $24 \mathrm{~h}$ and $48 \mathrm{~h}$ biofilm supernatants from 1.4 to $30.8 \%$ and from 1.3 to $40.2 \%$, respectively $(P<0.05)$ (Fig. 6c). When S. aureus biofilms are grown on the PC, the percentage of produced siderophore units increased from an undetectable level to $71 \%(P<0.05)$ when the biofilm growth temperature increased from 20 to $37{ }^{\circ} \mathrm{C}$ whatever the incubation duration of the biofilm formation (Fig. 6b). In addition, our data showed that the amount of produced siderophore by sessile cells grown on PC was significantly higher than that of their planktonic and SS counterparts whatever the studied conditions $(P<0.05)$ (Fig. 6a-c). 

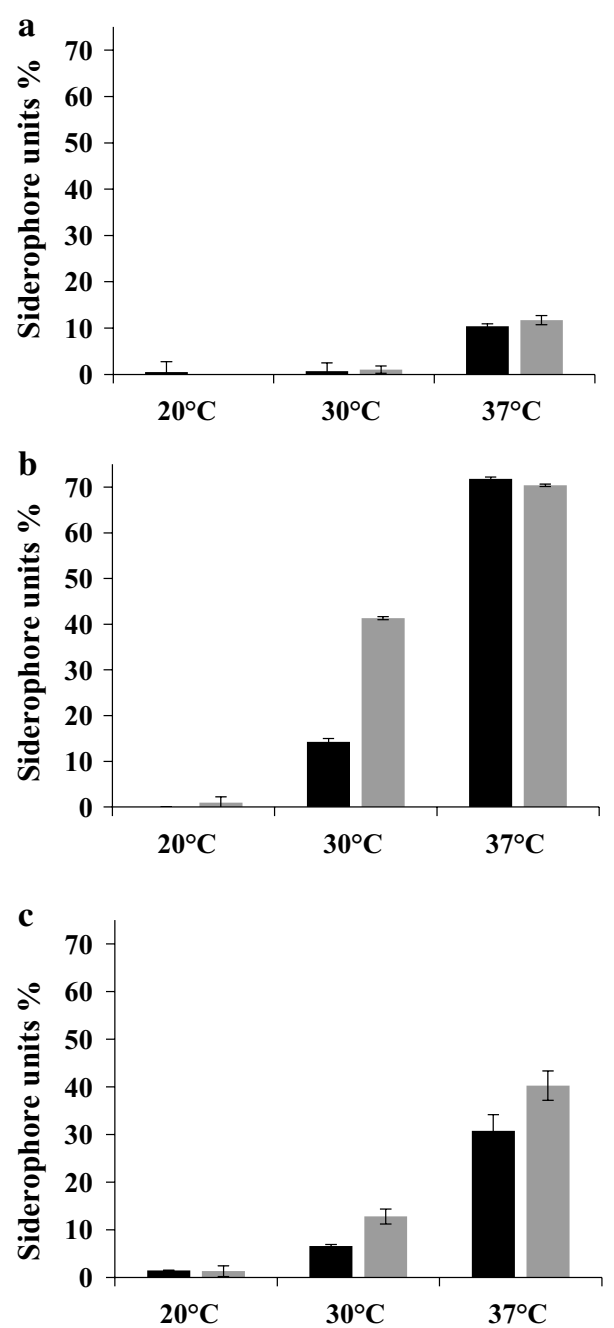

Fig. 6 Quantification of siderophore in Staphylococcus aureus culture supernatants. Cell cultures were grown at 20,30 and $37^{\circ} \mathrm{C}$, during $24 \mathrm{~h}$ (black square) and $48 \mathrm{~h}$ (grey square). Planktonic cells (a), biofilm grown on polycarbonate (b), biofilm grown on stainless steel (c)

\section{Discussion}

Bacterial adhesion and biofilm formation have become a serious problem in healthcare and food sectors, and much investigations have been done for better understanding of the processes involved. However, most of studies have focused on the bacterial adhesion of planktonic cells but have not considered the biofilm-detached cells which may be involved in contamination spread. It has been reported that the physiology of planktonic and biofilm-detached cells are deeply different (Stewart and Costerton 2001; Donlan and Costerton 2002). In this context, our study investigated, in particular, the impact of growth conditions on the physicochemical properties of biofilm-detached and planktonic $S$. aureus cells and on their ability to adhere to the SS and PC. Overall, our results showed that the increase of temperature and the incubation duration slightly increased the adhesion of $S$. aureus to the SS and the PC. These results are in agreement with previous studies which highlighted the effect of these parameters on the adhesion of S. aureus (Abdallah et al. 2014b), Listeria monocytogenes (Gordesli and Abu-Lail 2012) and Escherichia coli (Tsuji and Yokoigawa 2012) to different surfaces. Furthermore, our results showed that biofilm-detached cells had a higher adhesion rate than that of their planktonic counterparts. The same trend was reported by Berlanga et al. (2015), who underlined the greater ability of biofilm-detached Halomonas venusta cells to colonize new surfaces compared to their planktonic counterparts. By contrast, other studies (Allison et al. 1990), reported that there were no significant differences between the adhesion of biofilm-detached and planktonic E. coli cells to abiotic surfaces. Furthermore, we investigated the effect of growth conditions on the surface physicochemical properties of $S$. aureus cells. Overall, we showed that the hydrophobicity of biofilmdetached and planktonic S. aureus cells increased when the growth temperature increased from 20 to $37{ }^{\circ} \mathrm{C}$. These findings seem to be consistent with those of Abdallah et al. (2014a), who found that the hydrophobicity of $S$. aureus increased with the increase of the growth temperatures. Therefore, this result may explain the increase of S. aureus adhesion onto SS and PC. However, and if we consider, particularly, the results related to the bacterial surface hydrophobicity we could suggest that cell adhesion should be greater on hydrophobic supports such as the $\mathrm{PC}$ which is not the case under our experimental conditions. In accordance with a previous study (Abdallah et al. 2014a), our results showed a greater adhesion rate of $S$. aureus cells on SS than on the PC. Such results highlight that the hydrophobic interactions cannot always explain the bacterial adhesion onto abiotic surfaces. It has been reported that the acid-base interactions are the main forces governing the bacterial adhesion to abiotic surfaces (Bos et al. 1999). Our study highlighted the decrease of the electron donor character of 48 h-biofilmdetached cells with the increase of growth temperature. This may result in a decrease of repulsive acid-base interactions between the cells and the abiotic surfaces. Such decrease may, therefore, explain the increase of the bacterial adhesion of 48 h-biofilm-detached cells on the SS. By contrast, our results also showed that the electron donor characters of $S$. aureus did not always explain the differences found in the experimental results. In fact, the increase of electron donor character of $24 \mathrm{~h}$-biofilmdetached-cells, with the increase of growth temperature from 20 to $37^{\circ} \mathrm{C}$, was accompanied by an increase of the bacterial adhesion on both surfaces. Furthermore, we 
investigated the involvement of electrostatic interactions in the S. aureus adhesion to the SS and the PC. Our results showed that the $\mathrm{ZP}$ of $S$. aureus cells was negative whatever the studied conditions. Our findings also showed that biofilm-detached cells are less negatively charged than their planktonic counterparts, probably due to the up-regulation of cationic staphylococcal poly$\mathrm{N}$-acetylglucosamine surface polysaccharide (Otto 2008). Therefore, the low relative negative charge of biofilmdetached cells may result in a decrease of repulsive electrostatic forces between cells and negatively charged abiotic surfaces, which may explain their greater adhesion rates on abiotic surfaces as compared to that of their planktonic counterparts. Furthermore, our results showed that the increase of the growth temperature may result in a decrease of repulsive electrostatic interactions, between negatively-charged bacterial cells and abiotic surfaces. Therefore, this may explain the enhanced adhesion of the biofilm-detached S. aureus cells onto the SS. By contrast, our data showed that the increase of the growth temperature resulted in a decrease of the zeta potential of the biofilm-detached cells and simultaneously in an increase of the bacterial adhesion to the PC. Hence, we suggest that the electrostatic interactions may not always explain the bacterial adhesion to abiotic surfaces which involves other factors related to the cell envelope in this process (Hori and Matsumoto 2010). This work also investigated the effect of the growth conditions on the pathogenicity and cytotoxicity of the different studied S. aureus cultures. The DNase activity of biofilm cultures was greater than that of the planktonic cultures. In addition, the results showed that the DNase activity increased with the increase of the growth temperature and the incubation duration. These results are in disagreement with other studies (Resch et al. 2005; Wang et al. 2011), which underlined that the virulence factor production by planktonic $S$. aureus was greater compared to that of biofilm cultures. However, our results seem in line with those of Coenye et al. (2007), who stated that the sessile Propionibacterium acnes cells produced more virulence factors than the planktonic ones and this production increased with the increase of the incubation time. The present findings also appear to be in agreement with those of Mahoney et al. (2010), who underlined that the bacterial virulence regulation is influenced by the growth temperature. Furthermore, our findings showed that BCSs had a higher cytotoxic effect, on HeLa cells, than the PCSs whatever the studied condition. The cytotoxic effect of BCSs and PCSs increased in response to the increase of the temperature and the incubation duration. Taken together, our results may explain the influence of growth conditions on the bacterial metabolism controlling the production of virulence factors (Holler et al. 1998). According to Secor et al. (2011), the different metabolic states in planktonic and biofilm cultures likely have a large impact on the pathogenic effects on human cells. Thus, in our case, the important cytotoxic effect of $S$. aureus BCSs compared to that of PCSs could be related to the presence of higher amounts of virulence factors including exoenzymes such as DNase, which may disturb the biological activity of human cells (Modun and Williams 1999; Pancholi and Chhatwal 2003; Jarosław et al. 2005; Secor et al. 2011). Nevertheless, our results showed that BCSs recovered from biofilms grown on the PC surface were more cytotoxic to HeLa cells than those of biofilm grown on SS. Interestingly, our investigation showed that the siderophore production, which is enhanced under iron-limiting conditions (Vasil and Ochsner 1999; Gaonkar 2015), in the supernatant of biofilm grown on PC were higher than that of biofilm grown on SS. It has been reported that iron and nickel could be released from the SS into solution (Ortiz et al. 2011). Therefore, the limited availability of iron in the medium of biofilm grown on the PC, which is a plastic surface, could enhance the production of siderophores (Gaonkar 2015). In S. aureus, the greater production of siderophores correlated with higher virulence and more resistant (Rozalska et al. 1998; Dale et al. 2004). Taken together, our findings and previous studies may explain the greater cytotoxicity and pathogenicity of supernatants recovered from $S$. aureus biofilms grown on the PC when compared to those recovered from biofilms grown on the SS.

In conclusion, this study showed that biofilmdetached-cells are phenotypically distinct from planktonically grown cells. Moreover, our results showed that the bacterial history and the growth conditions affect the adhesion of $S$. aureus to abiotic surfaces by influencing the bacterial surface physicochemical properties. Our investigations also underlined the hazardous characters of biofilm-detached cells which appeared to be abler to adhere to abiotic surfaces than their planktonic counterparts. Such results highlight the importance of considering cell detachment as a serious stage in the process of biofilm development. These results should contribute to more effective management of disinfection strategies, especially by ensuring a rapid removal and killing of cells detached from contaminated surfaces to prevent the persistence and the spread of contamination. However, our findings underlined that the bacterial physicochemical properties cannot always fully explain the bacterial adhesion. An interesting perspective would consist in focusing on the quantification of bacterial adhesion forces using atomic force microscopy in order to extend the knowledge of the mechanisms mediating bacterial adhesion to abiotic surfaces and to develop new strategies for 
the prevention of the biofilm formation. In addition, our results showed that sessile cells produce higher amounts of different virulence factors which represent a serious threat in case of human infection by $S$. aureus. Interestingly, growth temperatures close to that of the human body increased the cells virulence potential and cytotoxicity to human cells. Moreover, biofilm formed on plastic surfaces, such as PC, showed higher pathogenic risk than those formed on metallic ones, such as SS. Thus, our results highlight that the presence biofilm on plastic indwelling medical devices such as catheters, may increase the risk of severe infections. Our work offers a novel insight into the infectious potential of $S$. aureus, which suggests that a virulent strains may increase their virulence by forming a biofilm and achieve persistent infection in vivo.

\begin{abstract}
Abbreviations
S. aureus: Staphylococcus aureus; ${ }^{\circ} \mathrm{C}$ : degree centigrade; h: hour; SS: stainless steel; PC: polycarbonate; TSB: tryptic soy broth; \%: percent; $\mu$ l: microliter; ml: milliliter; mm: millimeter; $\mu \mathrm{m}$ : micrometer; $\mathrm{nm}$ : nanometer; T: temperature; CFU: colony-forming unit; min: minutes; PPB: potassium phosphate buffer; mM: millimolar; M: molar; kHz: kilohertz; MATS: microbial adhesion to solvents; ZP: zeta potential; $\mathrm{H}_{2} \mathrm{O}$ : water; $\mathrm{KNO}_{3}$ : potassium nitrate; $\mathrm{KOH}$ : potassium hydroxide; $\mathrm{HCL}$ : hydrogenchloride; $\mathrm{CO}_{2}$ : carbon dioxide; $\mathrm{FBS}$ : phosphate buffered saline; DMEM: Dulbecco's modified eagle's medium; CCK: cell counting kit; DNA: deoxyribonucleic acid; DNase: deoxyribonuclease; CAS: chrome azurol sulphonate; mV: millivolt; PCBDC: polycarbonate-biofilm-detachedcells; SSBDC: stainless steel-biofilm-detached-cells; PCS: planktonic-culturesupernatants; BCS: biofilm-culture-supernatants; g: gravitational acceleration.
\end{abstract}

\begin{abstract}
Authors' contributions
SOK performed all measurements and experiments and drafted the manuscript. NEC supervised and provided important intellectual content in the research design, coordination of the study and contributed in the drafting of the manuscript. CJ and MA participated in the drafting and reviewing of the manuscript, analyzed the data and contributed to the statistical analysis. RB participated in the determination of the cytotoxic effects of supernatant samples. CF helped to perform zeta potential measurements. All authors read and approved the final manuscript.
\end{abstract}

\section{Author details}

${ }^{1}$ CNRS, ENSCL, UMR 8207-UMET-PSI, Université de Lille1, Avenue Dimitri Mendeleïev, CS 90108, 59652 Villeneuve d'Ascq, France. ${ }^{2}$ CNRS, INRA, UMR 8207-UMET-PIHM, Université de Lille1, 369 rue Jules Guesde, CS 20039, 59651 Villeneuve d'Ascq, France. ${ }^{3}$ CNRS, IEMN, UMR 8520, Université de Lille1, Cité Scientifique, Avenue Poincaré, 59652 Villeneuve d'Ascq, France.

\section{Acknowledgements}

This work was carried out within the framework of an ALIBIOTECH (Agroalimentaire et Biotechnologie, Nord Pas-de-Calais region) program. The authors also thank the Haut de France region and FEDER (Fonds européen de développement régional) for their financial support.

\section{Competing interests}

The authors declare that they have no competing interests.

\section{Availability of data and materials}

All data are fully available without restriction.

\section{Consent for publication}

Not applicable.
Ethics approval and consent to participate

Not applicable.

Funding

Not applicable.

\section{Publisher's Note}

Springer Nature remains neutral with regard to jurisdictional claims in published maps and institutional affiliations.

Received: 25 August 2017 Accepted: 14 October 2017

Published online: 24 October 2017

\section{References}

Abdallah M, Benoliel C, Jama C, Drider D, Dhulster P, Chihib N-E (2014a) Thermodynamic prediction of growth temperature dependence in the adhesion of Pseudomonas aeruginosa and Staphylococcus aureus to stainless steel and polycarbonate. J Food Prot 77:1116-1126. doi:10.4315/0362028X.JFP-13-365

Abdallah M, Chataigne G, Ferreira-Theret P, Benoliel C, Drider D, Dhulster P, Chihib N-E (2014b) Effect of growth temperature, surface type and incubation time on the resistance of Staphylococcus aureus biofilms to disinfectants. Appl Microbiol Biotechnol 98:2597-2607. doi:10.1007/ s00253-013-5479-4

Abdallah M, Khelissa O, Ibrahim A, Benoliel C, Heliot L, Dhulster P, Chihib $N-E$ (2015) Impact of growth temperature and surface type on the resistance of Pseudomonas aeruginosa and Staphylococcus aureus biofilms to disinfectants. Int J Food Microbiol 214:38-47. doi:10.1016/j. ijfoodmicro.2015.07.022

Allison DG, Evans DJ, Brown MR, Gilbert P (1990) Possible involvement of the division cycle in dispersal of Escherichia coli from biofilms. J Bacteriol 172:1667-1669

Bayoudh S, Othmane A, Mora L, Ouada HB (2009) Assessing bacterial adhesion using DLVO and XDLVO theories and the jet impingement technique. Colloids Surf B Biointerfaces 73:1-9. doi:10.1016/j.colsurfb.2009.04.030

Bellon-Fontaine M-N, Rault J, van Oss CJ (1996) Microbial adhesion to solvents: a novel method to determine the electron-donor/electron-acceptor or Lewis acid-base properties of microbial cells. Colloids Surf B 7:47-53. doi:10.1016/0927-7765(96)01272-6

Berlanga M, Domènech O, Guerrero R (2015) Biofilm formation on polystyrene in detached vs. planktonic cells of polyhydroxyalkanoate-accumulating Halomonas venusta. Int Microbiol 17:205-212

Bos R, van der Mei HC, Busscher HJ (1999) Physico-chemistry of initial microbial adhesive interactions-its mechanisms and methods for study. FEMS Microbiol Rev 23:179-230

Coenye T, Peeters E, Nelis HJ (2007) Biofilm formation by Propionibacterium acnes is associated with increased resistance to antimicrobial agents and increased production of putative virulence factors. Res Microbiol 158:386-392. doi:10.1016/j.resmic.2007.02.001

Dale SE, Doherty-Kirby A, Lajoie G, Heinrichs DE (2004) Role of siderophore biosynthesis in virulence of Staphylococcus aureus: identification and characterization of genes involved in production of a siderophore. Infect Immun 72:29-37

Donlan RM (2002) Biofilms: microbial life on surfaces. Emerg Infect Dis 8:881-890. doi:10.3201/eid0809.020063

Donlan RM, Costerton JW (2002) Biofilms: survival mechanisms of clinically relevant microorganisms. Clin Microbiol Rev 15:167-193. doi:10.1128/ CMR.15.2.167-193.2002

Fux CA, Wilson S, Stoodley P (2004) Detachment characteristics and oxacillin resistance of Staphylococcus aureus biofilm emboli in an in vitro catheter infection model. J Bacteriol 186:4486-4491. doi:10.1128/ JB.186.14.4486-4491.2004

Gaonkar T (2015) Eubacterial siderophores and factors modulating their production. In: Borkar S (ed) Bioprospects of coastal Eubacteria. Springer International Publishing, Cham, pp 25-38 
Garrett TR, Bhakoo M, Zhang Z (2008) Bacterial adhesion and biofilms on surfaces. Prog Nat Sci 18:1049-1056. doi:10.1016/j.pnsc.2008.04.001

Gordesli FP, Abu-Lail NI (2012) The role of growth temperature in the adhesion and mechanics of pathogenic Listeria monocytogenes: an AFM study. Langmuir 28:1360-1373. doi:10.1021/la203639k

Harris L, Foster S, Richards R (2002) An introduction to staphylococcus aureus, and techniques for identifying and quantifying S. aureus adhesins in relation to adhesion to biomaterials: review. Eur Cell Mater 4:39-60. doi:10.22203/eCM.v004a04

Holler C, Witthuhn D, Janzen-Blunck B (1998) Effect of low temperatures on growth, structure, and metabolism of Campylobacter coli SP10. Appl Environ Microbiol 64:581-587

Hori K, Matsumoto S (2010) Bacterial adhesion: from mechanism to control. Biochem Eng J 48:424-434. doi:10.1016/j.bej.2009.11.014

Jarosław J, Komar A, Jankowska E, Martirosian G (2005) Determination of the cytotoxic effect of Clostridium histolyticum culture supernatant on HeLa cells in the presence of protease inhibitors. FEMS Immunol Med Microbiol 45:137-142. doi:10.1016/j.femsim.2005.03.005

Khelissa SO, Abdallah M, Jama C, Faille C, Chihib NE (2017) Bacterial contamination and biofilm formation on abiotic surfaces and strategies to overcome their persistence. J Mater Environ Sci 8:3326-3346

Lewis K (2001) Riddle of biofilm resistance. Antimicrob Agents Chemother 45:999-1007. doi:10.1128/AAC.45.4.999-1007.2001

Mahoney JC, Gerding MJ, Jones SH, Whistler CA (2010) Comparison of the pathogenic potentials of environmental and clinical Vibrio parahaemolyticus strains indicates a role for temperature regulation in virulence. Appl Environ Microbiol 76:7459-7465. doi:10.1128/AEM.01450-10

Modun B, Williams P (1999) The staphylococcal transferrin-binding protein is a cell wall glyceraldehyde-3-phosphate dehydrogenase. Infect Immun 67:1086-1092

Nickel JC, Costerton JW, McLean RJ, Olson M (1994) Bacterial biofilms: influence on the pathogenesis, diagnosis and treatment of urinary tract infections. J Antimicrob Chemother 33(Suppl A):31-41

Normanno G, Corrente M, La Salandra G, Dambrosio A, Quaglia NC, Parisi A, Greco G, Bellacicco AL, Virgilio S, Celano GV (2007) Methicillin-resistant Staphylococcus aureus (MRSA) in foods of animal origin product in Italy. Int J Food Microbiol 117:219-222. doi:10.1016/j.ijfoodmicro.2007.04.006

Oogai Y, Matsuo M, Hashimoto M, Kato F, Sugai M, Komatsuzawa H (2011) Expression of virulence factors by Staphylococcus aureus grown in serum. Appl Environ Microbiol 77:8097-8105. doi:10.1128/AEM.05316-11

Ortiz AJ, Fernandez E, Vicente A, Calvo JL, Ortiz C (2011) Metallic ions released from stainless steel, nickel-free, and titanium orthodontic alloys: toxicity and DNA damage. Am J Orthod Dentofac Orthop 140:e115-e122. doi:10.1016/j.ajodo.2011.02.021

Otto M (2008) Staphylococcal biofilms. Curr Top Microbiol Immunol 322:207-228
Pancholi V, Chhatwal GS (2003) Housekeeping enzymes as virulence factors for pathogens. Int J Med Microbiol 293:391-401. doi:10.1078/1438-4221-00283

Percival SL, Suleman L, Vuotto C, Donelli G (2015) Healthcare-associated infections, medical devices and biofilms: risk, tolerance and control. J Med Microbiol 64:323-334. doi:10.1099/jmm.0.000032

Poulsen LV (1999) Microbial biofilm in food processing. LWT Food Sci Technol 32:321-326. doi:10.1006/fstl.1999.0561

Resch A, Rosenstein R, Nerz C, Gotz F (2005) Differential gene expression profiling of Staphylococcus aureus cultivated under biofilm and planktonic conditions. Appl Environ Microbiol 71:2663-2676. doi:10.1128/ AEM.71.5.2663-2676.2005

Rozalska B, Lisiecki P, Sadowska B, Mikucki J, Rudnicka W (1998) The virulence of Staphylococcus aureus isolates differing by siderophore production. Acta Microbiol Pol 47:185-194

Schwyn B, Neilands JB (1987) Universal chemical assay for the detection and determination of siderophores. Anal Biochem 160:47-56. doi:10.1016/0003-2697(87)90612-9

Secor PR, James GA, Fleckman P, Olerud JE, McInnerney K, Stewart PS (2011) Staphylococcus aureus biofilm and planktonic cultures differentially impact gene expression, mapk phosphorylation, and cytokine production in human keratinocytes. BMC Microbiol 11:143. doi:10.1186/1471-2180-11-143

Stewart PS, Costerton JW (2001) Antibiotic resistance of bacteria in biofilms. Lancet 358:135-138

Teixeira P, Lima J, Azeredo J, Oliveira R (2008) Adhesion of Listeria monocytogenes to materials commonly found in domestic kitchens. Int J Food Sci Technol 43:1239-1244. doi:10.1111/j.1365-2621.2007.01598.x

Tsuji M, Yokoigawa K (2012) Attachment of Escherichia coli O157:H7 to abiotic surfaces of cooking utensils. J Food Sci 77:M194-M199. doi:10.1111/j.1750-3841.2012.02654x

Valaperta R, Tejada MR, Frigerio M, Moroni A, Ciulla E, Cioffi S, Capelli P, Costa E (2010) Staphylococcus aureus nosocomial infections: the role of a rapid and low-cost characterization for the establishment of a surveillance system. New Microbiol 33:223-232

Vasil ML, Ochsner UA (1999) The response of Pseudomonas aeruginosa to iron: genetics, biochemistry and virulence. Mol Microbiol 34:399-413

Wang Y, Zhang W, Wu Z, Lu C (2011) Reduced virulence is an important characteristic of biofilm infection of Streptococcus suis. FEMS Microbiol Lett 316:36-43. doi:10.1111/j.1574-6968.2010.02189.x

Wilson S, Hamilton MA, Hamilton GC, Schumann MR, Stoodley P (2004) Statistical quantification of detachment rates and size distributions of cell clumps from wild-type (PAO1) and cell signaling mutant (JP1) Pseudomonas aeruginosa biofilms. Appl Environ Microbiol 70:5847-5852. doi:10.1128/AEM.70.10.5847-5852.2004

\section{Submit your manuscript to a SpringerOpen ${ }^{\odot}$ journal and benefit from:}

- Convenient online submission

- Rigorous peer review

- Open access: articles freely available online

- High visibility within the field

Retaining the copyright to your article

Submit your next manuscript at springeropen.com 